\title{
Strengthening capacity study of reinforced concrete school building structure in Banda Aceh toward earthquakes and tsunami hazards
}

\author{
Putri Istiqamah ${ }^{1 *}$, Siti Humayra ${ }^{1}$, and Huzaim ${ }^{2}$ \\ ${ }^{1}$ Student of Civil Engineering Department, Postgraduate Program, Syiah Kuala University, Jl. Syeh Abdurrauf, No. 7, Banda Aceh, \\ 23111, Indonesia \\ ${ }^{2}$ Civil Engineering Department, Faculty of Engineering, Syiah Kuala University, Jl. Syeh Abdurrauf, No. 7, Banda Aceh, 23111, \\ Indonesia
}

\begin{abstract}
Banda Aceh City was a high level areas of the earthquake and tsunami damage that occurred in 2004. Building damage prevention can be done by planning earthquake-resistant school building structures. The rebuilding needs to be reviewed for its capacity structure because of the high risk building location of earthquake and tsunami hazards. This study aims to determine the behavior and capacity of the school building structure using the earthquake and tsunami scenario in 2004 in Banda Aceh. Capacity analysis by column enlargement of the existing building is one of the research variables. Earthquake load refers to data from the Sumatera-Andaman earthquake on December 26, 2004 and tsunami load refers to FEMA P646. Two typical school buildings were taken from data recapitulation of 100 buildings survey, namely SDN 48 and SDN 8, which represented the overall typical school building in Banda Aceh. This study uses the pushover analysis method on the SAP2000 software. Based on the capacity curve, the value of displacement in the $x-y$ directions in the existing building are greater than the column variation building at SDN 48 and SDN 8. While the shear force value in the existing building are smaller than the column variation building. This shows that with the addition of column dimensions, the cross-sectional area gets bigger and affects the capacity of the building structure.
\end{abstract}

\section{Introduction}

Earthquake and tsunami are natural disasters that can cause casualties and buildings damage. Real evidence of this disaster could be seen in 2004, an earthquake measuring 9.3 SR that once rocked Banda Aceh City and was followed by a tsunami wave. The estimated impact of the 2004 earthquake and tsunami was that as many as 45,000 students and 1,870 teachers died, as well as damage to 2,065 educational facilities [2]. School buildings, especially elementary schools, are educational facilities that have a high priority index because they accommodate many of the burdens of life such as students and teachers. Prevention of damage to buildings caused by the earthquake and tsunami can be pursued by planning school building structures that meet the criteria for earthquake-resistant buildings, so that they can be used as temporary shelters in disaster emergency situations. The damage level to buildings is influenced by the strength and intensity of the earthquake, the configuration of the building structure, the stiffness and strength of the building structure, and the quality of building materials. Buildings that suffered light and moderate damage only needed repairs to certain parts, while buildings that suffered heavy damage and total damage required overall repairs to rebuilding. School buildings located in areas affected by the earthquake and tsunami need to be reviewed for their capacity to withstand earthquake and tsunami loads. This is related to efforts to minimize the potential damage caused by the earthquake and tsunami. This study uses earthquake and tsunami loading with earthquake and tsunami scenario in 2004. Capacity analysis by adding column dimensions from the existing building is one of the research variables. This variable will be simulated using parametric studies. The selection of research objects was carried out based on typical building criteria in the form of a top view of the building, number of floors, and building materials, as well as observe the condition of the building and the vulnerabilities found during the field survey. The results of data recapitulation on 100 school buildings and obtained two typical school buildings, namely SD Negeri 48 and SD Negeri 8 which represent the overall typical building in Banda Aceh City. The results of this study were obtained of displacement values, shear forces, and interstory drift to see the behavior of the building structure. The results of the capacity curve obtained from the pushover analysis are evaluated to obtain a comparison of the structural capacity values for the existing building and the column variation building. The capacity curve is converted into a capacity spectrum

\footnotetext{
*Putri Istiqamah: putriistiqamah13@gmail.com
} 
curve that can determine the level of damage to the building. The probability value for the level of building damage is determined using and the developed seismic and tsunami fragility curve, so it can be seen the level of damage that occurs to the building. So that with the addition of column dimensions it can be used as an effort to strengthen the capacity of the building structure. The limitation of the problem in this study is that the research location is in Banda Aceh area, the planning does not take into account the lower structure of the building, and the analysis of earthquake and tsunami loading is carried out separately.

\section{Literature review}

\subsection{Earthquake}

Earthquakes are defined as natural vibrations that occur at certain locations and are unsustainable. Earthquakes are usually caused by sudden movements of the earth's crust (plates). The sudden movement occurs because of a source of force as the cause, both from nature and from human assistance (artificial earthquakes) [11].

\subsection{Tsunami}

Tsunami waves cannot be seen when they are far in the middle of the ocean, but once they reach shallow areas the waves will move quickly. The energy generated by a tsunami is constant with respect to the function of altitude and its continuation [10].

\subsection{Earthquake resistant building structure}

Earthquake resistant buildings are defined as buildings that are able to withstand the design earthquake loads without experiencing excessive damage or not collapsing due to the earthquake [12].

\subsection{Structure behaviour}

\subsubsection{Displacement}

The degrees of freedom are the degrees of independence needed to express the position of a degree's system at any time. If a reviewed point experiences a displacement of $\mathrm{X}, \mathrm{Y}$, and $\mathrm{Z}$ direction, then the system has three degrees of freedom. This happens because the point in question can move freely in three directions [1].

\subsubsection{Inter-story drift}

The inter-story drift is the horizontal displacement at the top of the reviewed level relative to the bottom [1]. The determination of inter-story drift can be seen in Fig. 1.

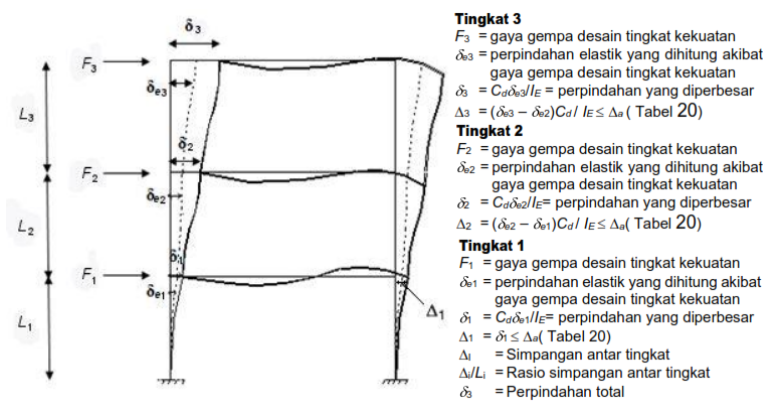

Fig. 1. Determination of Inter-story drift

\subsubsection{Base shear force}

Base shear force is the total design shear or lateral force that occurs at the base level [1]. The basic seismic shear force $(\mathrm{V})$ in the specified direction is determined by Eq. $(1-2)$ :

$$
\begin{aligned}
\mathrm{V} & =\mathrm{C}_{\mathrm{s}} \mathrm{W} \\
\mathrm{C}_{\mathrm{s}} & =\frac{S_{D S}}{\frac{R}{I_{e}}}
\end{aligned}
$$

\subsection{Pushover analysis}

Pushover analysis is a linear and nonlinear two or three dimensional static analysis method, where the influence of the design earthquake on the building structure is considered as static loads that capture the center of mass of each floor, whose value is gradually increased until it exceeds the loading, which causes the plastic hinge in the building structure, then with a further increase in load undergoes a large elastoplastic deformation until it reaches a condition on the verge of collapse [9].

\subsection{Seismic fragility curve}

Seismic fragility curve is a curve that shows the possibility of damage to a structure when it receives an earthquake load with a certain intensity. This curve becomes very important in assessing or evaluating the seismic performance of a structure because it displays the level of seismic fragility as a possible damage based on earthquake loads that exceed the design load on the performance or limit state of a particular structure [15]. Due to a statistical program, the probability values that form the fragility curve will be obtained as shown in Fig. 2. 

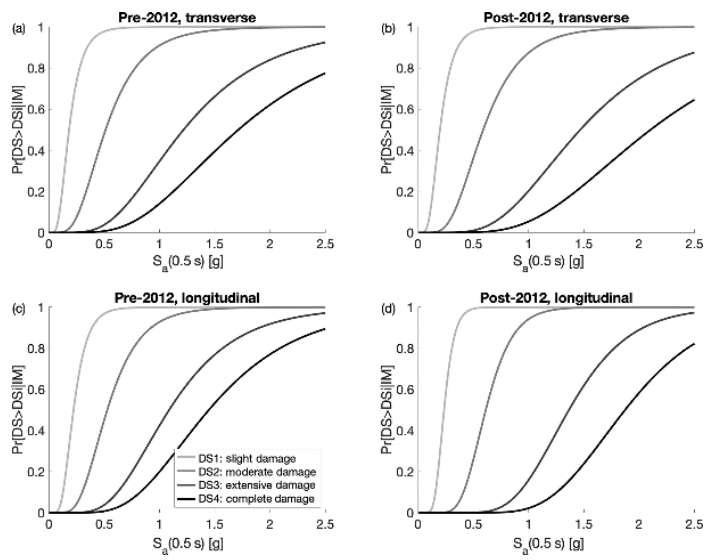

Fig. 2. Seismic fragility curves for typical buildings

The damage state of building structures according to Hazus [8] can be seen in Table 1 .

Table 1. The Performance Limitations of Structure.

\begin{tabular}{cl} 
Damage State & \multicolumn{1}{c}{ Description } \\
\hline Damage & $\begin{array}{l}\text { Small plaster cracks at corners of door } \\
\text { and window openings and wall ceiling } \\
\text { intersections; small cracks in masonry } \\
\text { chimneys and masonry veneers. Small } \\
\text { cracks are assumed to be visible with a } \\
\text { maximum width of less than 1/8 inch } \\
\text { (cracks wider than 1/8 inch are referred }\end{array}$ \\
to as "large" cracks). \\
\hline Eoderate & $\begin{array}{l}\text { Large plaster or gypsum-board cracks at } \\
\text { corners of door and window openings; } \\
\text { small diagonal cracks across shear wall } \\
\text { panels exhibited by small cracks in }\end{array}$ \\
stucco and gypsum wall panels; large \\
cracks in brick chimneys; toppling of tall \\
masonry chimneys.
\end{tabular}

\subsection{Tsunami fragility curve}

Tsunami fragility is defined as the structural damage probability or fatality ratio with particular regard to the hydrodynamic features of tsunami inundation flow, such as inundation depth, current velocity and hydrodynamic force. In principle, the development of tsunami fragility requires that tsunami hazard information and damage data should be used synergistically [7]. The tsunami fragility curve can be seen in Fig. 3 and the level of damage is in Table 2 [13].

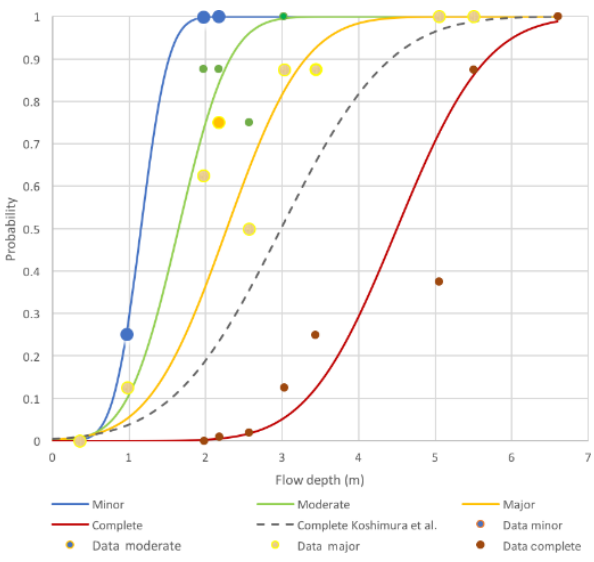

Fig. 3. Tsunami fragility curves for typical buildings

Table 2. Damage limit state of buildings due to tsunami

\begin{tabular}{cll}
\hline Classification & $\begin{array}{l}\text { Damage } \\
\text { Condition }\end{array}$ & \multicolumn{1}{c}{ Description } \\
\hline DC0 & $\begin{array}{l}\text { No } \\
\text { damages }\end{array}$ & $\begin{array}{l}\text { Flooded but no damages } \\
\text { found. }\end{array}$ \\
\hline DC1 & Minor & $\begin{array}{l}\text { Damages found windows } \\
\text { and doors, no damage on } \\
\text { wall and on structural } \\
\text { component }\end{array}$ \\
\hline DC2 & Moderate & $\begin{array}{l}\text { One side wall damages, no } \\
\text { damage on column and } \\
\text { beam. }\end{array}$ \\
\hline DC3 & Major & $\begin{array}{l}\text { All walls were damaged or } \\
\text { roofs felt down, structural } \\
\text { components bent/deflected } \\
\text { or broken. }\end{array}$ \\
& & Only floor left. \\
\hline DC4 & $\begin{array}{l}\text { Complete/ } \\
\text { Washed } \\
\text { away }\end{array}$ & \\
\hline
\end{tabular}

\section{Research methods}

\subsection{Object of research}

The object of research in this study is a typical two-story school building in Banda Aceh City with reinforced concrete construction. The determination of the building type is carried out by recapitulating survey data from 100 school buildings and taking two typical buildings that dominate the structural design of the building.

\subsection{Research data}

The types of data needed in this study are:

1. Primary data is data obtained directly from the results of filling out data forms through field surveys on school buildings in Banda Aceh City in the form of data on the dimensions of building structural elements.

2. Secondary data is supporting data and a reference for the implementation of the primary survey. This data is obtained from relevant agencies in a ready-to-use form.

3. The literature used is SNI-1726-2019, SNI-03-17272020, Map of Sources and Earthquake Hazards in Indonesia, as well as books related to research. 


\subsection{Data collection technique}

Research data collection was carried out by means of a field survey. Surveys are used to collect building structure data and building vulnerability factors by looking directly at the condition of the building. Structural data collection was carried out randomly on 100 school buildings in Banda Aceh using a rapid assessment survey, so that the distribution of surveyed school buildings was achieved for each sub-district in Banda Aceh.

\subsubsection{Building technical data}

Typical details of building structures for various building forms in Banda Aceh are as shown in Table 3 [5].

Table 3. Typical structural detail for typical school buildings in Banda Aceh

\begin{tabular}{|c|c|c|c|c|}
\hline & Materials & $\begin{array}{l}\text { Typical } \\
\text { Beam }\end{array}$ & $\begin{array}{l}\text { Typical } \\
\text { Column }\end{array}$ & $\begin{array}{c}\text { Typical } \\
\text { Joint }\end{array}$ \\
\hline \multirow[t]{3}{*}{$\begin{array}{l}\text { Pre- } \\
2012\end{array}$} & $\begin{array}{l}\text { Concrete, } \\
\mathrm{f}_{\mathrm{c}}=21,5 \mathrm{Mpa}\end{array}$ & $3 \Phi 16$ top & $3 \Phi 16$ top & \multirow{3}{*}{$\begin{array}{c}\text { No } \\
\text { stirrups }\end{array}$} \\
\hline & $\begin{array}{l}\text { Long. steel, } \\
\mathrm{f}_{\mathrm{y}}=400 \mathrm{Mpa}\end{array}$ & $\begin{array}{l}3 \Phi 16 \\
\text { bottom }\end{array}$ & $\begin{array}{l}3 \Phi 16 \\
\text { bottom }\end{array}$ & \\
\hline & $\begin{array}{l}\text { Long. steel, } \\
\mathrm{f}_{\mathrm{y}}=240 \mathrm{Mpa}\end{array}$ & $\begin{array}{l}\text { Ф10@150 } \\
\text { mm } \\
\text { stirrups }\end{array}$ & $\begin{array}{l}\text { Ф10@200 } \\
\text { mm } \\
\text { stirrups }\end{array}$ & \\
\hline \multirow[t]{3}{*}{$\begin{array}{l}\text { Post- } \\
2012\end{array}$} & $\begin{array}{l}\text { Concrete, } \\
\mathrm{f}_{\mathrm{c}}=24 \mathrm{Mpa}\end{array}$ & $3 \Phi 16$ top & $3 \Phi 16$ top & \multirow{3}{*}{$\begin{array}{c}\text { No } \\
\text { stirrups }\end{array}$} \\
\hline & $\begin{array}{l}\text { Long. steel, } \\
\mathrm{f}_{\mathrm{y}}=400 \mathrm{Mpa}\end{array}$ & $\begin{array}{l}3 \Phi 16 \\
\text { bottom }\end{array}$ & $\begin{array}{l}3 \Phi 16 \\
\text { bottom }\end{array}$ & \\
\hline & $\begin{array}{l}\text { Long. steel, } \\
\mathrm{f}_{\mathrm{y}}=240 \mathrm{Mpa}\end{array}$ & $\begin{array}{l}\text { Ф10@150 } \\
\text { mm } \\
\text { stirrups }\end{array}$ & $\begin{array}{l}\Phi 10 @ 100 \\
\text { mm } \\
\text { stirrups }\end{array}$ & \\
\hline
\end{tabular}

\subsubsection{Earthquake data}

The Earthquake data used is recorded earthquake data that occurred in Sumatra - Andaman fault on December 26th, 2004 obtained from United States Geological Survey (USGS).

\subsubsection{Tsunami data}

The tsunami data needed to calculate the tsunami load [4] is the depth of the tsunami flow in 2004 [6] and the difference in the elevation of the building subgrade to the water level [14].

\subsection{Building structure modeling}

The reviewed structure in this study is the entire structure of the school building. The structural modeled using SAP2000 software as a space frame.

The data entered are detail building data, the quality of the materials used, the dimensions of the building, and the loading. The modeling structure of each school building is done with two variations of the column in the same way.
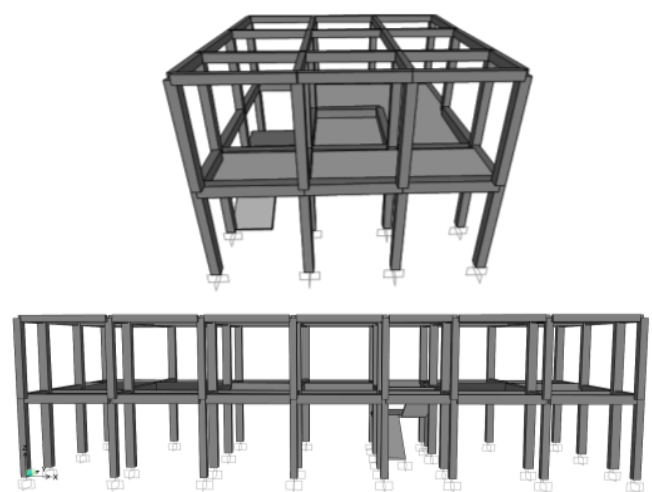

Fig. 4. 3D structure model

\subsection{Loading}

Loads that are inputted in the SAP2000 program are dead loads, live loads, earthquake loads, tsunami loads, and combined loads.

1. Combined earthquake loading

$\mathrm{U}_{1}=1,4 \mathrm{D}$

$\mathrm{U}_{2}=1,2 \mathrm{D}+1,6 \mathrm{~L}$

$\mathrm{U}_{3}=1,38 \mathrm{D}+1 \mathrm{~L}+0,39 \mathrm{Q}_{\mathrm{Ex}}+1,3 \mathrm{QEy}$

$\mathrm{U}_{4}=1,38 \mathrm{D}+1 \mathrm{~L}+0,39 \mathrm{QEx}_{\mathrm{Ex}}-1,3 \mathrm{Q} \mathrm{Ey}$

$\mathrm{U}_{5}=1,38 \mathrm{D}+1 \mathrm{~L}-0,39 \mathrm{Q} \mathrm{Ex}-1,3 \mathrm{QEy}$

$\mathrm{U}_{6}=1,38 \mathrm{D}+1 \mathrm{~L}-0,39 \mathrm{Q}_{\mathrm{Ex}}+1,3 \mathrm{Q} \mathrm{Ey}$

$\mathrm{U}_{7}=1,38 \mathrm{D}+1 \mathrm{~L}+1,3 \mathrm{Q}_{\mathrm{Ex}}+0,39 \mathrm{Q} \mathrm{Ey}$

$\mathrm{U}_{8}=1,38 \mathrm{D}+1 \mathrm{~L}+1,3 \mathrm{Q}_{\mathrm{Ex}}-0,39 \mathrm{Q} \mathrm{Ey}$

$\mathrm{U}_{9}=1,38 \mathrm{D}+1 \mathrm{~L}-1,3 \mathrm{Q}_{\mathrm{Ex}}-0,39 \mathrm{Q} \mathrm{Ey}$

$\mathrm{U}_{10}=1,38 \mathrm{D}+1 \mathrm{~L}-1,3 \mathrm{Q}_{\mathrm{Ex}}+0,39 \mathrm{Q}_{\mathrm{Ey}}$

$\mathrm{U}_{11}=1,08 \mathrm{D}+0,39 \mathrm{Q}_{\mathrm{Ex}}+1,3 \mathrm{QEy}$

$\mathrm{U}_{12}=1,08 \mathrm{D}+0,39 \mathrm{Q}_{\mathrm{Ex}}-1,3 \mathrm{QEy}$

$\mathrm{U}_{13}=1,08 \mathrm{D}-0,39 \mathrm{Q}_{\mathrm{Ex}}-1,3 \mathrm{Q} \mathrm{Ey}$

$\mathrm{U}_{14}=1,08 \mathrm{D}-0,39 \mathrm{Q}_{\mathrm{Ex}}+1,3 \mathrm{QEy}$

$\mathrm{U}_{15}=1,08 \mathrm{D}+1,3 \mathrm{Q}_{\mathrm{Ex}}-0,39 \mathrm{Q}_{\mathrm{Ey}}$

$\mathrm{U}_{16}=1,08 \mathrm{D}+1,3 \mathrm{Q}_{\mathrm{Ex}}+0,39 \mathrm{Q}$ Ey

$\mathrm{U}_{17}=1,08 \mathrm{D}-1,3 \mathrm{Q}_{\mathrm{Ex}}-0,39 \mathrm{Q}_{\mathrm{Ey}}$

$\mathrm{U}_{18}=1,08 \mathrm{D}-1,3 \mathrm{Q}_{\mathrm{Ex}}+0,39 \mathrm{QEy}$

2. Combined tsunami loading

$\mathrm{U}_{19}=1,2 \mathrm{D}+1,0 \mathrm{~T}_{\mathrm{S}}+1,0 \mathrm{~L}_{\mathrm{REF}}+0,25 \mathrm{~L}$

$\mathrm{U}_{20}=0,9 \mathrm{D}+1,0 \mathrm{TS}$

\subsection{Pushover analysis}

Pushover analysis is done by loading in stages, the lateral loading carried out represents the earthquake force on each floor. The lateral loading direction is carried out in direction of the main axis building. Lateral loading uses the displacement-controlled concept, which the loading process is increased gradually until the displacement target is achieved.

\subsection{Tsunami loading}

The tsunami load used is hydrostatic force, hydrodynamic force, and debris impact force. These forces are calculated with a flow depth of 7 meters. The hydrostatic force is input as distributed load, pyramidal shaped along the flooded column. The hydrodynamic force is input as distributed load along the flooded 
column. While the debris impact force is inputted as a point load. These forces are input in the y-direction. Then analysis was carried out on SAP2000 software using a combination of $19\left(\mathrm{U}_{19}\right)$ and a combination of 20 $\left(\mathrm{U}_{20}\right)$.

\subsection{Data analysis}

\subsubsection{The dynamic characteristics structure analysis}

Analysis of the dynamic characteristics structure is produced by performing a free vibration analysis. The dynamic characteristics of this structure consist of a natural mode shape and a natural period of vibration. In this study, free vibration analysis was performed using eigen value analysis and Ritz vector which was built in in the SAP2000 program.

\subsubsection{The capacity curve and capacity spectrum curve analysis}

The capacity curve is the result of pushover analysis in SAP2000. The capacity curve shows the behavior of the building structure when given an earthquake load at a certain level. The median spectral acceleration $\left(\mathrm{S}_{\mathrm{a}}\right)$ value is obtained by converting the capacity curve into a capacity spectrum curve which is the spectral acceleration $\left(\mathrm{S}_{\mathrm{a}}\right)$ curve to spectral displacement $\left(\mathrm{S}_{\mathrm{d}}\right)$. The capacity spectrum curve was analyzed to obtain the median spectra displacement and median spectral acceleration values at various levels of damage [3].

\subsection{Developed seismic fragility curve analysis}

Seismic fragility curve shows the probability of damage to the structure under consideration when receiving earthquake loads with a certain intensity. Once the probability value obtained is used to determine the coordinates of the fragility curve as the ordinate axis (y) with the value $S_{a}$ on the seismic fragility curve. The fragility curve is converted using an online graph-reader application to extract values from graphic images as shown in Fig. 5.

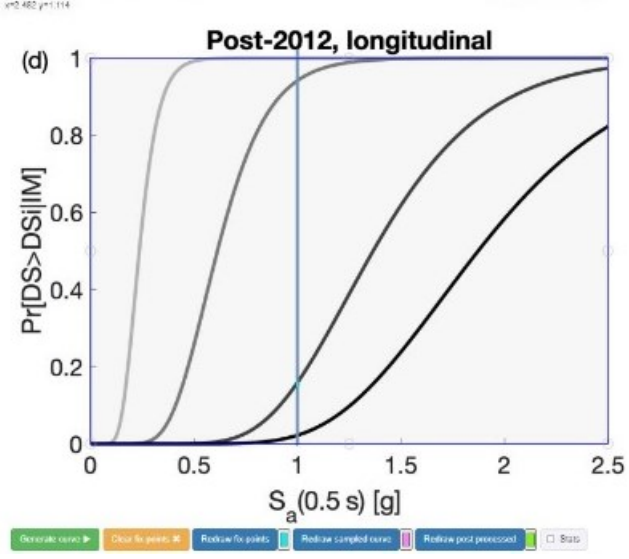

Fig. 5. Online graph-reader application display

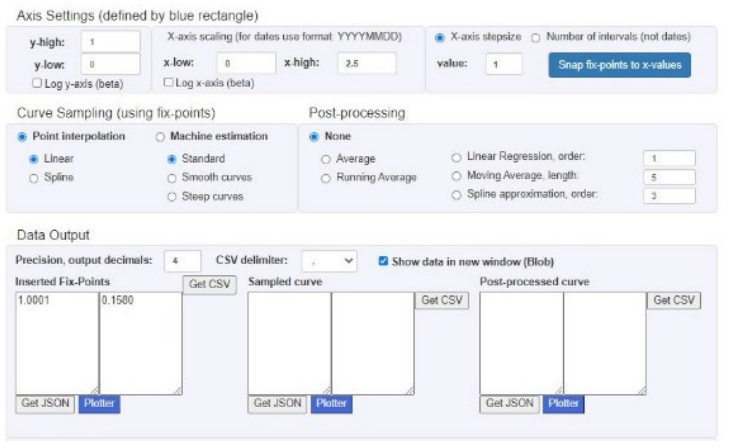

Fig. 6. Graph-reader output data results

\subsection{Reinforcement analysis}

After earthquake loading, structural capacity analysis is carried out on the results of displacement, shear force, and inter-story drift that occurs for the two typical buildings. The same method is also carried out on the column variation building for the two typical buildings. While for the tsunami load, the results from SAP2000 are seen for the inter-story drift that occurred. The result of this research is the comparison of the capacity structure that occurs between the existing and column variation building.

\section{Results and discussion}

\subsection{Survey data recapitulation results}

The recapitulation data was conducted to determine the object of research which is a typical school building in Banda Aceh. From the recapitulation results, an infographic is made to show the criteria for school buildings that dominate in Banda Aceh which can be seen in Fig. 6.
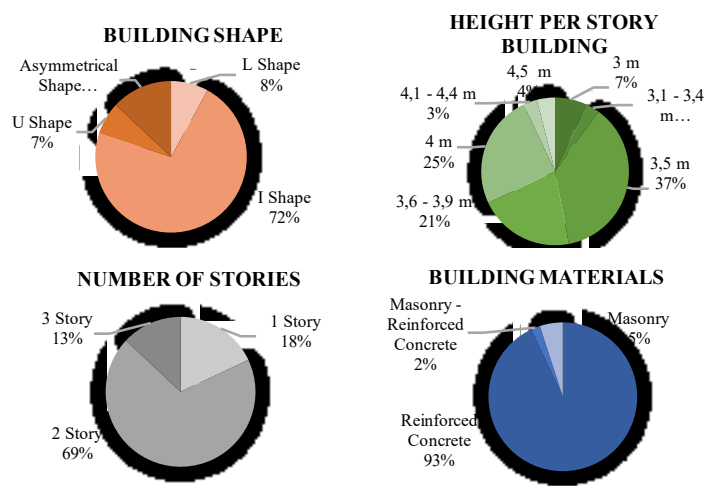

Fig. 6. Infographic data results

Based on the infographic, the building criteria obtained are in the building shape with I shape of $72 \%$, the height of story building is $3.5 \mathrm{~m}$ with a percentage of $37 \%$, a two-story building is $69 \%$, and reinforced concrete building materials are $93 \%$. In addition to these criteria, the selection of research objects is also influenced by the condition of the building and the vulnerabilities found during the field survey. School buildings that meet the criteria from the conclusion above are SD Negeri 48 Banda Aceh located in Kutaraja District and SD Negeri 
8 Banda Aceh located in Meuraxa District. The technical data for the school buildings of SD Negeri 48 and SD Negeri 8 Banda Aceh can be seen in Table 4.

Table 4. Characteristics and building position

\begin{tabular}{clll}
\hline & \multicolumn{1}{c}{ Criteria } & \multicolumn{1}{c}{ SD Negeri 48 } & \multicolumn{1}{c}{ SD Negeri 8 } \\
\hline 1 & $\begin{array}{l}\text { Place } \\
\text { Coordinates }\end{array}$ & $\begin{array}{l}\text { Longitude } \\
95.2898 ; \\
\text { Latitude 5.5586 }\end{array}$ & $\begin{array}{l}\text { Longitude } \\
95.31060 ; \\
\text { Latitude 5.56041 }\end{array}$ \\
\hline 2 & $\begin{array}{l}\text { Construction } \\
\text { Year }\end{array}$ & 2015 & 2016 \\
\hline 3 & $\begin{array}{l}\text { Number of } \\
\text { stories }\end{array}$ & Two-story & Two-story \\
\hline 4 & $\begin{array}{l}\text { Height per } \\
\text { story }\end{array}$ & 3,5 meters & 3,5 meters \\
\hline 5 & Materials & $\begin{array}{l}\text { Reinforced } \\
\text { Concrete (RC) }\end{array}$ & $\begin{array}{l}\text { Reinforced } \\
\text { Concrete (RC) }\end{array}$ \\
\hline 6 & Frame system & Space Frame & Space Frame \\
\end{tabular}

\subsection{Number of variety analysis results}

Based on the analysis results on SAP2000, it shows that the modal load participation value of the existing and column variation building in the SDN 48 and SDN 8 has met the provisions of the SNI $03-1726-2019$ limit (in Table 5), which the effective mass participation factor for UX and UY is a minimum of $90 \%$.

Table 5. Results of analysis of fundamental vibration time of structure

\begin{tabular}{|c|c|c|c|c|}
\hline Building & $\begin{array}{l}\text { Modal } \\
\text { Type }\end{array}$ & Item & $\begin{array}{l}\text { Static } \\
(\%)\end{array}$ & $\begin{array}{c}\text { Dynamic } \\
(\%)\end{array}$ \\
\hline \multirow{3}{*}{$\begin{array}{l}\text { SDN } 48 \\
\text { (Existing } \\
\text { Building) }\end{array}$} & Acceleration & UX & 100 & 99,5253 \\
\hline & Acceleration & UY & 100 & 98,7962 \\
\hline & Acceleration & $\mathrm{UZ}$ & 1,1327 & 0,1718 \\
\hline \multirow{3}{*}{$\begin{array}{l}\text { SDN 48 } \\
\text { (Column } \\
\text { Variation } \\
\text { Building) }\end{array}$} & Acceleration & UX & 100 & 99,5654 \\
\hline & Acceleration & UY & 100 & 98,2429 \\
\hline & Acceleration & $\mathrm{UZ}$ & 0,7664 & 0,1377 \\
\hline \multirow{3}{*}{$\begin{array}{c}\text { SDN 8 } \\
\text { (Existing } \\
\text { Building) }\end{array}$} & Acceleration & UX & 100 & 99,8135 \\
\hline & Acceleration & UY & 100 & 99,7223 \\
\hline & Acceleration & $\mathrm{UZ}$ & 1,0103 & 0,6771 \\
\hline \multirow{3}{*}{$\begin{array}{c}\text { SDN } 8 \\
\text { (Column } \\
\text { Variation } \\
\text { Building) }\end{array}$} & Acceleration & UX & 100 & 99,7351 \\
\hline & Acceleration & UY & 100 & 99,6714 \\
\hline & Acceleration & $\mathrm{UZ}$ & 0,8748 & 0,6763 \\
\hline
\end{tabular}

\subsection{Result of analysis of fundamental period of structure}

Based on the analysis results on SAP2000, it shows that the natural period of the existing and column variation building in the SDN 48 and SDN 8 has met the provisions of the SNI $03-1726-2019$ (in Table 6.) with natural period limit of 0.3759 seconds.
Table 6. Results of analysis of fundamental vibration time of structure

\begin{tabular}{cccc}
\hline Building & Period & $\mathbf{T}_{\mathbf{a} \text { izin }}$ & \\
\cline { 2 - 3 } Description \\
\hline $\begin{array}{c}\text { SDN 48 } \\
\text { (Existing Building) }\end{array}$ & 0,2274 & 0,3759 & $\checkmark$ \\
\hline $\begin{array}{c}\text { SDN 48 } \\
\text { (Column Variation } \\
\text { Building) }\end{array}$ & 0,1728 & 0,3759 & $\checkmark$ \\
\hline $\begin{array}{c}\text { SDN 8 } \\
\text { (Existing Building) }\end{array}$ & 0,2209 & 0,3759 & $\checkmark$ \\
\hline $\begin{array}{c}\text { SDN 8 } \\
\text { (Column Variation } \\
\text { Building) }\end{array}$ & 0,16054 & 0,3759 & $\checkmark$ \\
\hline
\end{tabular}

\subsection{Displacement analysis results}

The maximum displacement due to the combination of $\mathrm{x}-\mathrm{y}$ direction earthquake loads for existing and column variations buildings and can be seen in Table 7 .

Table 7. Maximum displacement result of SDN 48

\begin{tabular}{|c|c|c|c|c|c|c|}
\hline & \multicolumn{3}{|c|}{$\begin{array}{c}\text { SDN 48 } \\
\text { (Existing Building) }\end{array}$} & \multicolumn{3}{|c|}{$\begin{array}{c}\text { SDN 48 } \\
\text { (Column Variation } \\
\text { Building) }\end{array}$} \\
\hline & \multirow{2}{*}{$\dot{\Xi}$} & \multirow[t]{2}{*}{$\stackrel{\mathscr{0}}{\stackrel{\Xi}{\varrho}}$} & $\begin{array}{c}\text { Displac } \\
\text { ement } \\
\text { Max. }\end{array}$ & \multirow{2}{*}{$\dot{\ddot{\theta}}$} & \multirow[t]{2}{*}{ 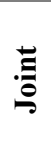 } & $\begin{array}{c}\text { Displac } \\
\text { ement } \\
\text { Max. }\end{array}$ \\
\hline & & & $\mathbf{m}$ & & & $\mathbf{m}$ \\
\hline $\begin{array}{c}\mathrm{X}- \\
\text { direction }\end{array}$ & $\mathrm{U}_{4}$ & 49 & 0,1198 & $\mathrm{U}_{4}$ & 50 & 0,0850 \\
\hline $\begin{array}{c}\mathrm{Y}- \\
\text { direction }\end{array}$ & $\mathrm{U}_{6}$ & 56 & 0,0839 & $\mathrm{U}_{6}$ & 56 & 0,0622 \\
\hline
\end{tabular}

Table 7. Maximum Displacement Result of SDN 8

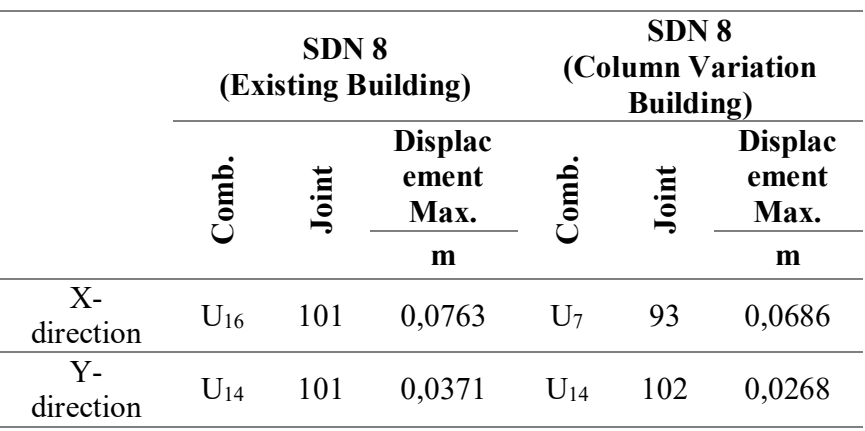

\subsection{Shear force analysis results}

The basic shear force $\left(V_{t}\right) \geq V$, where the calculation of the basic shear force value for each building is as follows (eq. 1):

$$
\begin{aligned}
& \mathrm{S}_{\mathrm{DS}}=0,9 \mathrm{~g} \\
& \mathrm{~S}_{1}=0,75 \mathrm{~g} \\
& \mathrm{I}_{\mathrm{e}}=1,5 \\
& \mathrm{R}=8
\end{aligned}
$$

The coefficient of $\mathrm{C}_{\mathrm{s}}$ must be determined by:

$$
\mathrm{C}_{\mathrm{s}}=\frac{S_{D S}}{\frac{R}{I_{e}}}=\frac{0,9}{\frac{8}{1,5}}=0,075
$$


For structures located in areas where $S_{1} \geq 0,6 \mathrm{~g}$, the $\mathrm{C}_{\mathrm{s}}$ must be not less than:

$$
\mathrm{C}_{\mathrm{s}}=\frac{0,5 \times S_{1}}{\frac{R}{I_{e}}}=\frac{0,5 \times 0,75}{\frac{8}{1,5}}=0,0703
$$

So, the value of $C_{s}$ used for this analysis is 0,0703 .

Table 8. Basic shear force calculation

\begin{tabular}{cll}
\hline \multirow{2}{*}{ Building } & \multicolumn{1}{c}{$\mathbf{V}_{\text {syarat }}$} & \multicolumn{1}{c}{$\mathbf{0 , 8 5} \mathbf{V}_{\text {syarat }}$} \\
\cline { 2 - 2 } s.W & $=0,85(5327,399)$ \\
SDN 48 & $=0,0703(75780,93)$ & $=4528,289 \mathrm{kgf}$ \\
(Existing & $=5327,399 \mathrm{kgf}$ & \\
Building) & & $=0,85(6567,491)$ \\
\hline SDN 48 & $=0,0703(93420,93)$ & $=5582,367 \mathrm{kgf}$ \\
(Column & $=6567,491 \mathrm{kgf}$ & \\
Variation & & \\
Building) & & $=0,85(14786,106)$ \\
\hline SDN 8 & $=0,0703(210328,67)$ & \\
(Existing & $=14786,106 \mathrm{kgf}$ & $=12568,19 \mathrm{kgf}$ \\
Building) & & $=0,85(17431,635)$ \\
\hline SDN 48 & $=0,0703(247960,67)$ & $=14816,89 \mathrm{kgf}$ \\
(Column & $=17431,635 \mathrm{kgf}$ & \\
Variation & & \\
Building) & & \\
\hline
\end{tabular}

Table 9. Base shear force results

\begin{tabular}{cccccc}
\hline \multirow{2}{*}{ Building } & $\mathbf{V}$ & \multicolumn{3}{c}{ Base Shear $\left(\mathbf{V}_{\mathbf{t}}\right)$} \\
& $\mathbf{K g f}$ & $\mathbf{V}_{\mathbf{t x}}$ & $\mathbf{V}_{\mathbf{t y}}$ & \multicolumn{2}{c}{$\mathbf{V}_{\mathbf{t}}>\mathbf{V}$} \\
\hline SDN 48 & 4528,29 & 6031,03 & 255,52 & $\checkmark$ & $\mathbf{x}$ \\
(Existing & & & & & \\
Building) & & & & & \\
\hline SDN 48 & $5,582,37$ & 28689,31 & 8601,34 & $\checkmark$ & $\checkmark$ \\
(Column & & & & & \\
Variation & & & & & \\
Building) & & & & & \\
\hline SDN 8 & 12568,19 & 316131,16 & 235916,26 & $\checkmark$ & $\checkmark$ \\
(Existing & & & & & \\
Building) & & & & & \\
\hline SDN 8 & 14816,89 & 377150,87 & 292761,01 & $\checkmark$ & $\checkmark$ \\
(Column & & & & & \\
Variation & & & & & \\
Building) & & & & & \\
\hline
\end{tabular}

Based on the Table 9, the value of the basic y-direction shear force for the existing SDN 48 building is not greater than the value of the allowable shear force. So that this value does not meet the provisions of SNI 17262019. After the column variation, the result of the basic shear force obtained is greater than the value of the allowable shear force. While the basic shear force for the existing building and the column variation building at SDN 8 has met the requirements because the resulting value is greater than the allowable shear force value.

\subsection{The result of the analysis inter-story drift with earthquake load}

Berdasarkan SNI 1726:2019, The value of the interstory drift must be less than 0,01 or $1 \%$ times the height of the building before the floor level under review for risk category IV buildings. The results of the calculation of the deviation between levels in the $\mathrm{x}$ and $\mathrm{y}$ directions due to the earthquake can be seen in Table 4.8 and Table 4.9 .

Table 10. Inter-story drift with earthquake load x-direction

\begin{tabular}{|c|c|c|c|c|c|}
\hline Building & $\frac{\overrightarrow{0}}{\dot{0}}$ & 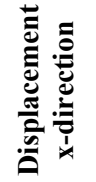 & 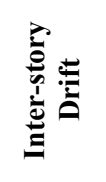 & $\begin{array}{c}\text { Inter-story } \\
\text { Drift Ratio } \\
\mathbf{0 , 0 1 0} \mathbf{h}_{\mathbf{s x}}\end{array}$ & 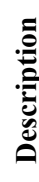 \\
\hline & & m & m & m & \\
\hline \multirow{2}{*}{$\begin{array}{l}\text { SDN } 48 \\
\text { (Existing } \\
\text { Building) }\end{array}$} & 2 & 0,1149 & 0,0572 & 0,035 & $x$ \\
\hline & 1 & 0,0577 & 0,0577 & 0,035 & $x$ \\
\hline \multirow{2}{*}{$\begin{array}{l}\text { SDN } 48 \\
\text { (Column } \\
\text { Variation } \\
\text { Building) }\end{array}$} & 2 & 0,0691 & 0,0344 & 0,035 & $\checkmark$ \\
\hline & 1 & 0,0347 & 0,0347 & 0,035 & $\checkmark$ \\
\hline \multirow{2}{*}{$\begin{array}{c}\text { SDN 8 } \\
\text { (Existing } \\
\text { Building) }\end{array}$} & 2 & 0,0678 & 0,0252 & 0,035 & $\checkmark$ \\
\hline & 1 & 0,0427 & 0,0427 & 0,035 & $x$ \\
\hline \multirow{2}{*}{$\begin{array}{l}\text { SDN } 8 \\
\text { (Column } \\
\text { Variation } \\
\text { Building) }\end{array}$} & 2 & 0,0657 & 0,0337 & 0,035 & $\checkmark$ \\
\hline & 1 & 0,0320 & 0,0320 & 0,035 & $\checkmark$ \\
\hline
\end{tabular}

Table 11. Inter-story drift with earthquake load y-direction

\begin{tabular}{|c|c|c|c|c|c|}
\hline Building & $\frac{\overrightarrow{0}}{\infty}$ & 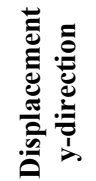 & 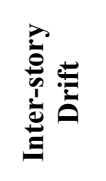 & $\begin{array}{c}\text { Inter-story } \\
\text { Drift Ratio }\end{array}$ & 苛 \\
\hline & & (m) & (m) & (m) & \\
\hline \multirow{2}{*}{$\begin{array}{l}\text { SDN } 48 \\
\text { (Existing } \\
\text { Building) }\end{array}$} & 2 & 0,0838 & 0,0163 & 0,035 & $\checkmark$ \\
\hline & 1 & 0,0675 & 0,0675 & 0,035 & $x$ \\
\hline \multirow{2}{*}{$\begin{array}{c}\text { SDN } 48 \\
\text { (Column } \\
\text { Variation } \\
\text { Building) }\end{array}$} & 2 & 0,0522 & 0,0244 & 0,035 & $\checkmark$ \\
\hline & 1 & 0,0278 & 0,0278 & 0,035 & $\checkmark$ \\
\hline \multirow{2}{*}{$\begin{array}{c}\text { SDN } 8 \\
\text { (Existing } \\
\text { Building) }\end{array}$} & 2 & 0,0871 & 0,0352 & 0,035 & $x$ \\
\hline & 1 & 0,0519 & 0,0519 & 0,035 & $x$ \\
\hline \multirow{2}{*}{$\begin{array}{c}\text { SDN } 8 \\
\text { (Column } \\
\text { Variation } \\
\text { Building) }\end{array}$} & 2 & 0,0265 & 0,0126 & 0,035 & $\checkmark$ \\
\hline & 1 & 0,0139 & 0,0139 & 0,035 & $\checkmark$ \\
\hline
\end{tabular}

\subsection{Capacity curve evaluation results}

The capacity curve is nonlinear due to an increase in load which makes the structural elements of the building change from an elastic condition to a plastic condition. 

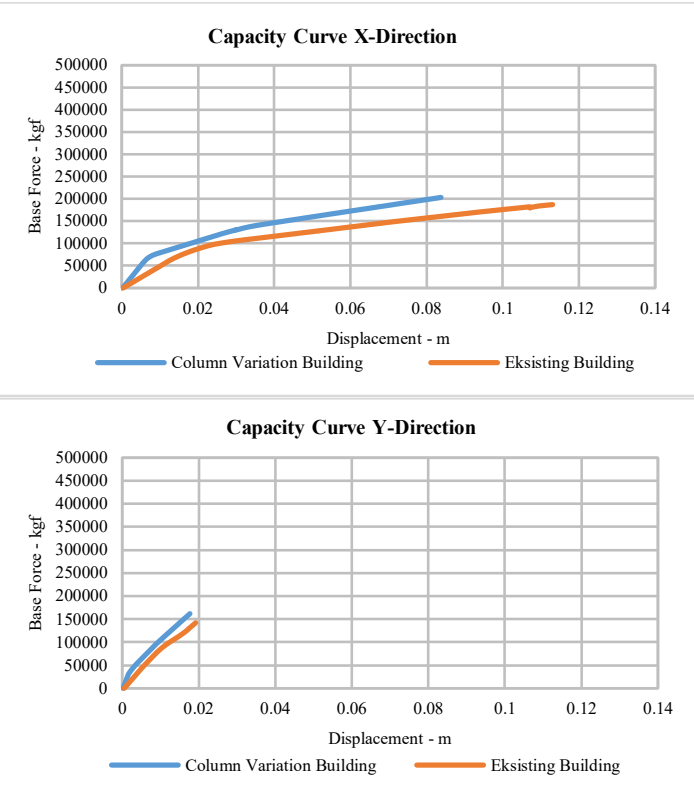

Fig. 7. Capacity curve $x-y$ direction in SDN 48

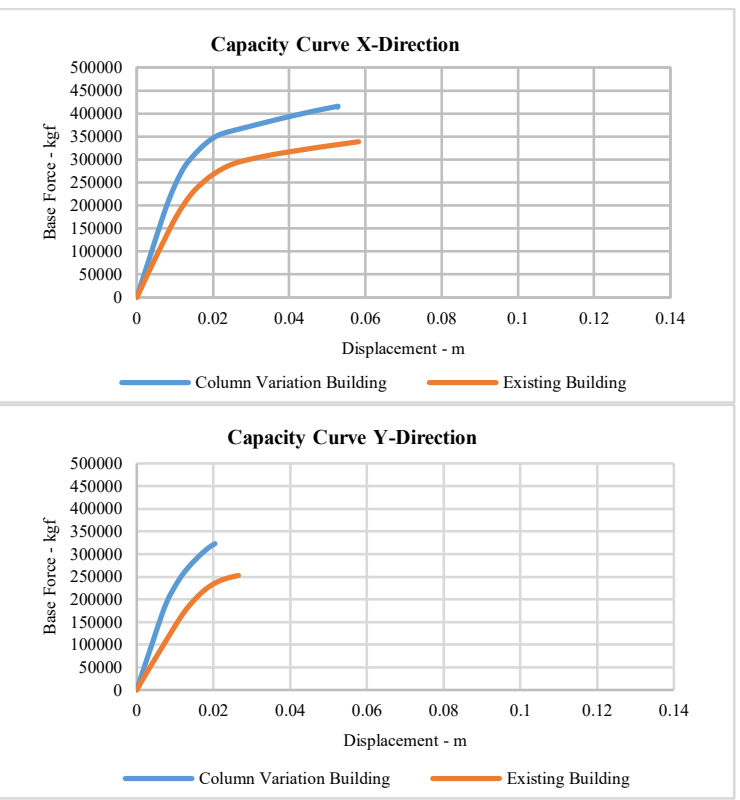

Fig. 8. Capacity curve $x-y$ direction in SDN 8

Based on the fig. 8, the value of displacement in the $\mathrm{x}$ and $y$ directions in the existing building is greater than the column variation building at SDN 48 and SDN 8 . While the shear force value in the existing building is smaller than the column variation building. This is influenced by the addition of column dimensions which results in a larger cross-sectional area. Overall, these results indicate that the existing buildings and column variations in both schools are more flexible and prone to shifts in the $\mathrm{x}$-direction.

\subsection{Capacity spectrum results}

The capacity spectrum curve aims to obtain the value of the median spectral acceleration parameter. Furthermore, on the capacity spectrum curve, the position of each damage limit is determined. Determination of the position of each damage limit on the capacity spectrum curve based on research [3].
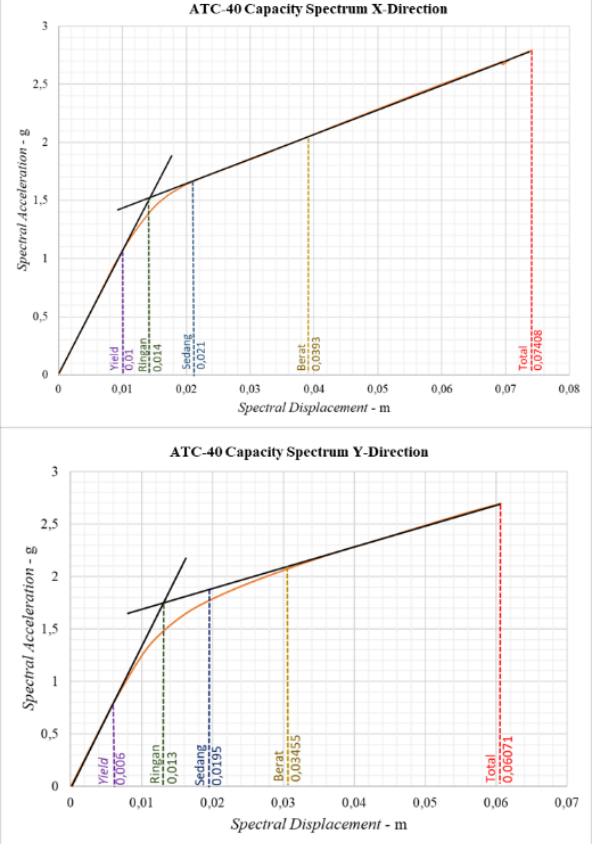

Fig. 9. Capacity spectrum $x-y$ directions of the existing building (SDN 48)
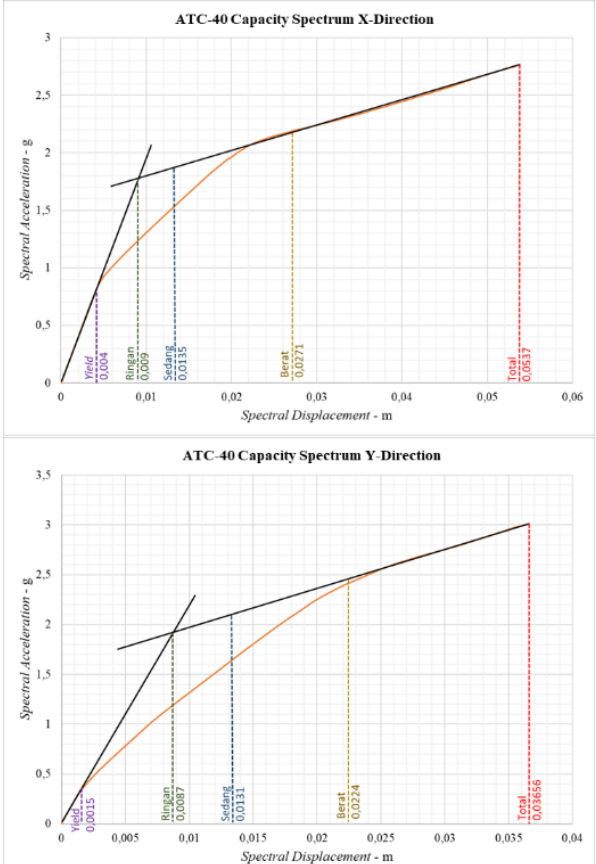

Fig. 10. Capacity spectrum $x-y$ directions of the column variation building (SDN 48)

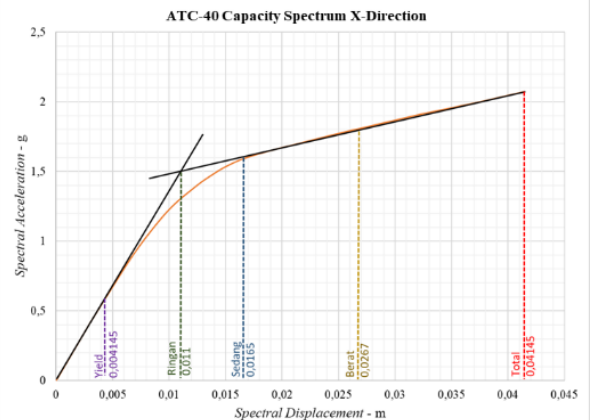




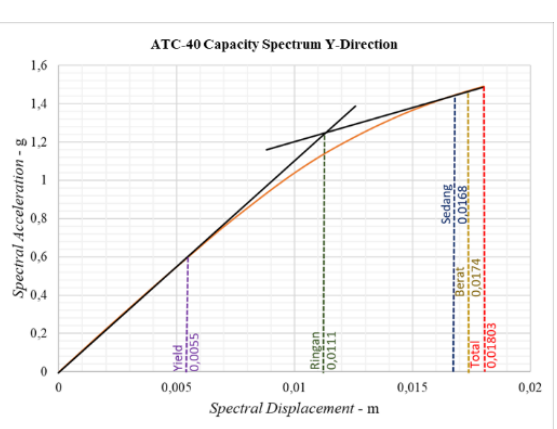

Fig. 11. Capacity spectrum $x-y$ directions of the existing building (SDN 8)

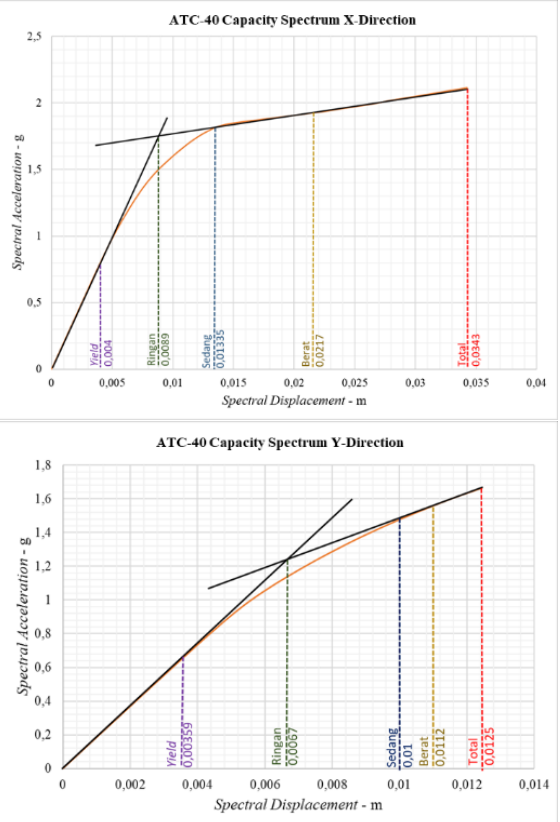

Fig. 12. Capacity spectrum $x-y$ directions of the column variation building (SDN 8)

The seismic fragility curve in buildings is the relationship between the spectral acceleration as the horizontal axis and the probability of structural failure as the vertical axis (Fig. 9-12). Based on the identification of the capacity spectrum curve, the resulting spectral displacement $\left(\mathrm{S}_{\mathrm{d}}\right)$ and spectral acceleration $\left(\mathrm{S}_{\mathrm{a}}\right)$ points for each structural failure condition can be seen in Table 12 and Table 13.

Table 12. $S_{d}$ and $S_{a}$ values for each type of structural damage at SDN 48 building

\begin{tabular}{cccccc}
\hline \multirow{2}{*}{ Building } & \multirow{2}{*}{$\begin{array}{c}\text { Damage } \\
\text { state }\end{array}$} & \multicolumn{2}{c}{ Sd, ds (m) } & \multicolumn{2}{c}{ Sa,ds (g) } \\
\cline { 3 - 6 } & $\begin{array}{c}\mathbf{x}- \\
\text { direction }\end{array}$ & $\begin{array}{c}\mathbf{y}- \\
\text { direction }\end{array}$ & $\begin{array}{c}\mathbf{x}- \\
\text { direction }\end{array}$ & $\begin{array}{c}\mathbf{y}- \\
\text { direction }\end{array}$ \\
\hline SDN 48 & Slight & 0,0140 & 0,0130 & 1,3808 & 1,4681 \\
\cline { 2 - 6 } (Existing & Moderate & 0,0210 & 0,0195 & 1,6613 & 1,7666 \\
Building) & Extensive & 0,0393 & 0,0346 & 2,0545 & 2,1640 \\
\cline { 2 - 6 } & Complete & 0,0741 & 0,0607 & 2,7928 & 2,6956 \\
\hline SDN 48 & Slight & 0,0091 & 0,0087 & 1,2440 & 1,1834 \\
\cline { 2 - 6 } (Column & Moderate & 0,0135 & 0,0131 & 1,5511 & 1,6225 \\
\cline { 2 - 6 } Variation & Extensive & 0,0271 & 0,0224 & 2,1898 & 2,4099 \\
Building) & Complete & 0,0537 & 0,0366 & 2,7677 & 3,0089 \\
\hline
\end{tabular}

Table 13. $S_{d}$ and $S_{a}$ values for each type of structural damage at SDN 8 building

\begin{tabular}{cccccc}
\hline \multirow{2}{*}{ Building } & \multirow{2}{*}{$\begin{array}{c}\text { Damage } \\
\text { state }\end{array}$} & \multicolumn{2}{c}{ Sd, ds (m) } & \multicolumn{2}{c}{ Sa,ds (g) } \\
\cline { 3 - 6 } & & $\begin{array}{c}\mathbf{x}- \\
\text { direction }\end{array}$ & $\begin{array}{c}\mathbf{y}- \\
\text { direction }\end{array}$ & $\begin{array}{c}\mathbf{x}- \\
\text { direction }\end{array}$ & $\begin{array}{c}\mathbf{y}- \\
\text { direction }\end{array}$ \\
\hline SDN 8 & Slight & 0,0110 & 0,0111 & 1,3015 & 1,1303 \\
(Existing & Moderate & 0,0165 & 0,0168 & 1,5869 & 1,4464 \\
Building) & Extensive & 0,0267 & 0,0174 & 1,8040 & 1,4694 \\
\cline { 2 - 6 } & Complete & 0,0414 & 0,0180 & 2,0706 & 1,4914 \\
\hline SDN 8 & Slight & 0,0089 & 0,0067 & 1,5053 & 1,1404 \\
\cline { 2 - 6 } (Column & Moderate & 0,0134 & 0,0100 & 1,8053 & 1,4762 \\
Variation & Extensive & 0,0217 & 0,0112 & 1,9262 & 1,5734 \\
Building) & Complete & 0,0343 & 0,0125 & 2,1113 & 1,6638 \\
\hline
\end{tabular}

\subsubsection{The results of the evaluation of the developed seismic fragility curve}

The required data is taken from the results of spectra response of PUSKIM (Pusat Penelitian dan Pengembangan Pemukiman). The seismic fragility curve used for this evaluation is the curve in the Gentile, et al (2019).

1. Calculation of $\mathrm{S}_{\mathrm{a}} \mathrm{SDN} 48$ building

$$
\begin{aligned}
\mathrm{T} & =0,3759 \mathrm{sec} \\
\mathrm{T}_{0} & =0.135983 \mathrm{sec} \\
\mathrm{T}_{\mathrm{S}} & =0.679916 \mathrm{sec} \\
\mathrm{T}_{\mathrm{L}} & =14.000000 \mathrm{sec} \\
\mathrm{S}_{\mathrm{ds}} & =1.000124 \mathrm{~g}
\end{aligned}
$$

Since $\mathrm{T} \geq \mathrm{T}_{0}$ or $\mathrm{T} \leq \mathrm{T}_{\mathrm{s}}$, then $\mathrm{S}_{\mathrm{a}}=\mathrm{S}_{\mathrm{ds}}, \mathrm{S}_{\mathrm{a}}=1,000124 \mathrm{~g}$. Data $S_{a}$ is inputted into the online graph-reader application and generates probability values as shown in Fig. 13.
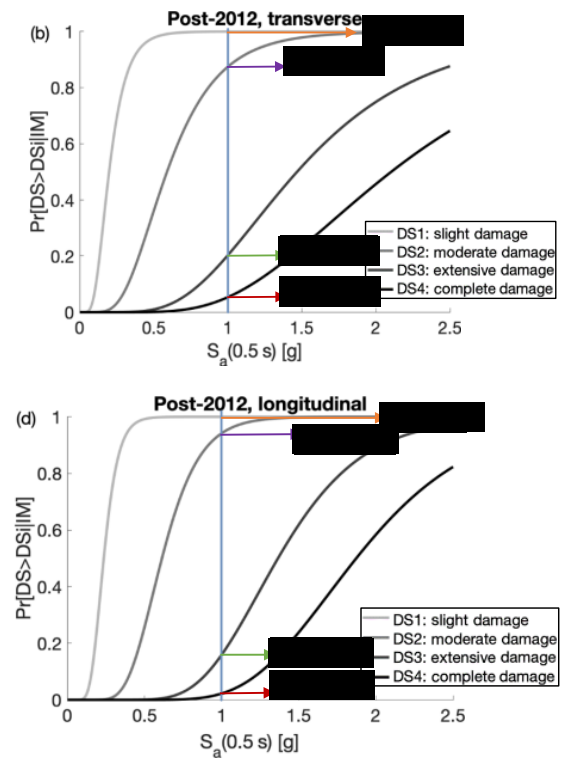

Fig. 13. Identification of the probability of the seismic fragility curve in the $\mathrm{x}$ and $\mathrm{y}$ directions of SDN 48 building

2. Calculation of $\mathrm{S}_{\mathrm{a}} \mathrm{SDN} 8$ building

$$
\begin{aligned}
\mathrm{T} & =0,3759 \mathrm{sec} \\
\mathrm{T}_{0} & =0,135831 \mathrm{sec} \\
\mathrm{T}_{\mathrm{s}} & =0,679154 \mathrm{sec} \\
\mathrm{T}_{\mathrm{L}} & =15,000000 \mathrm{sec} \\
\mathrm{S}_{\mathrm{ds}} & =1,001245 \mathrm{~g}
\end{aligned}
$$


Since $T \geq T_{0}$ or $T \leq T_{s}$, then $S_{a}=S_{d s}, S_{a}=1,001245 \mathrm{~g}$. Data $S_{a}$ is inputted into the online graph-reader application and generates probability values as shown in Fig. 14.
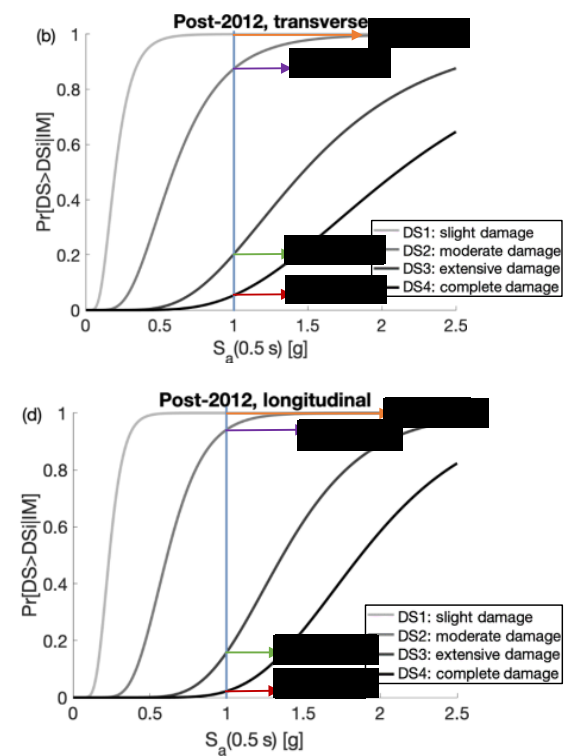

Fig. 14. Identification of the probability of the seismic fragility curve in the $\mathrm{x}$ and $\mathrm{y}$ directions of SDN 8 building.

\subsection{Structural reinforcement evaluation results}

Based on the results of the evaluation of the existing fragility curve, it shows that the buildings of SDN 48 and SDN 8 will experience slight and moderate conditions so that it can be recommended to carry out structural reinforcement. After adding 15\% column dimensions, table 4.9 shows the results of the structural capacity by connecting the values of displacement and base reaction and in Table 14 shows the largest displacement results for the $\mathrm{x}$ and $\mathrm{y}$ directions.

Table 14. Result of displacement direction $X$ and direction $\mathrm{Y}$

\begin{tabular}{|c|c|c|c|c|}
\hline \multirow{3}{*}{ ڤ્o } & \multirow{2}{*}{$\begin{array}{l}\text { Column } \\
\text { dimension }\end{array}$} & \multirow{2}{*}{$\begin{array}{c}\text { Column } \\
\text { dimension } \\
\text { enlargement }\end{array}$} & \multicolumn{2}{|c|}{ Displacement } \\
\hline & & & $\begin{array}{c}x- \\
\text { direction }\end{array}$ & $\begin{array}{c}\mathrm{y}- \\
\text { direction }\end{array}$ \\
\hline & cm & $\%$ & $\mathbf{m}$ & $\mathbf{m}$ \\
\hline \multirow{2}{*}{ SDN 48} & $30 \times 30$ & $0 \%$ & 0,1198 & 0,0839 \\
\hline & $40 \times 40$ & $15 \%$ & 0,0850 & 0,0622 \\
\hline \multirow{2}{*}{ SDN 8} & $\begin{array}{l}30 \times 30 \\
30 \times 40\end{array}$ & $0 \%$ & 0,0763 & 0,0371 \\
\hline & $\begin{array}{l}40 \times 40 \\
40 \times 50\end{array}$ & $15 \%$ & 0,0686 & 0,0268 \\
\hline
\end{tabular}

Based on the Table 14, in the SDN 48 building, the displacement value that occurred after adding the column dimensions were reduced by $29 \%$ for the $x$ direction and decreased by $26 \%$ for the y direction. Meanwhile, in SDN 8 building, the displacement value that occurs after adding the column dimensions is reduced by $10 \%$ for the $\mathrm{x}$ direction and $28 \%$ for the $\mathrm{y}$ direction. This shows that with the addition of column dimensions, the building structure becomes more rigid because the displacement results are getting smaller.

\subsection{Tsunami load analysis results}

FEMA P646 only explains how to calculate the tsunami load on the building, so that for checking, SNI 1726:2019 is used as a control for inter-story drift.

Table 15 Tsunami force calculation results

\begin{tabular}{lcc}
\hline \multirow{2}{*}{ Force } & \multicolumn{2}{c}{ Results } \\
\cline { 2 - 3 } SDN 48 & SDN 8 \\
\hline Hydrostatic force & $793138,5 \mathrm{~N}$ & $1057518 \mathrm{~N}$ \\
\hline $\begin{array}{l}\text { Hydrodynamic } \\
\text { force }\end{array}$ & $20848,2 \mathrm{~N}$ & $20508,3 \mathrm{~N}$ \\
\hline Debris impact force & - & $62584,1 \mathrm{~N}$ \\
\hline
\end{tabular}

The results of the inter-story drift of the combined tsunami load (Table 15) that occurred can be seen in Table 16 and Table 17.

Table 16 Inter-story drift with tsunami load X-direction

\begin{tabular}{|c|c|c|c|c|c|}
\hline Building & $\frac{\vec{c}}{\mathfrak{D}}$ & 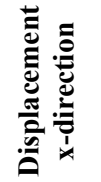 & 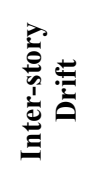 & $\begin{array}{c}\text { Inter-story } \\
\text { Drift Ratio } \\
\mathbf{0 , 0 1 0} \mathbf{h}_{\mathbf{s x}}\end{array}$ & .气 \\
\hline & & m & m & m & \\
\hline \multirow{2}{*}{$\begin{array}{l}\text { SDN } 48 \\
\text { (Existing } \\
\text { Building) }\end{array}$} & 2 & 0,0145 & 0,0013 & 0,035 & $\checkmark$ \\
\hline & 1 & 0,0132 & 0,0132 & 0,035 & $\checkmark$ \\
\hline \multirow{2}{*}{$\begin{array}{l}\text { SDN } 48 \\
\text { (Column } \\
\text { Variation } \\
\text { Building) }\end{array}$} & 2 & 0,0044 & 0,0009 & 0,035 & $\checkmark$ \\
\hline & 1 & 0,0035 & 0,0035 & 0,035 & $\checkmark$ \\
\hline \multirow{2}{*}{$\begin{array}{c}\text { SDN 8 } \\
\text { (Existing } \\
\text { Building) }\end{array}$} & 2 & 0,0020 & 0,0004 & 0,035 & $\checkmark$ \\
\hline & 1 & 0,0016 & 0,0016 & 0,035 & $\checkmark$ \\
\hline \multirow{2}{*}{$\begin{array}{l}\text { SDN } 8 \\
\text { (Column } \\
\text { Variation } \\
\text { Building) }\end{array}$} & 2 & 0,0020 & 0,0004 & 0,035 & $\checkmark$ \\
\hline & 1 & 0,0015 & 0,0015 & 0,035 & $\checkmark$ \\
\hline
\end{tabular}

Based on Table 16, the result of the inter-story drift in the $\mathrm{x}$-direction at SDN 48 and SDN 8 is smaller than the inter-story drift permit, so that it meets the provisions of SNI 1726-2019.

Table 17. Inter-story drift with tsunami load Y-direction

\begin{tabular}{|c|c|c|c|c|c|}
\hline Building & $\stackrel{\overrightarrow{0}}{\overrightarrow{0}}$ & 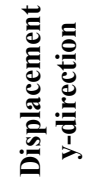 & 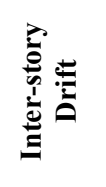 & $\begin{array}{c}\text { Inter-story } \\
\text { Drift Ratio } \\
\\
0,010 \text { h }_{\mathbf{s x}}\end{array}$ & 氮 \\
\hline & & (m) & (m) & (m) & \\
\hline \multirow{2}{*}{$\begin{array}{l}\text { SDN } 48 \\
\text { (Existing } \\
\text { Building) }\end{array}$} & 2 & 0,0671 & 0,0172 & 0,035 & $\checkmark$ \\
\hline & 1 & 0,0499 & 0,0499 & 0,035 & $x$ \\
\hline \multirow{2}{*}{ SDN 48} & 2 & 0,0201 & 0,0077 & 0,035 & $\checkmark$ \\
\hline & 1 & 0,0124 & 0,0124 & 0,035 & $\checkmark$ \\
\hline
\end{tabular}




\begin{tabular}{cccccc}
\cline { 2 - 5 } $\begin{array}{c}\text { (Column } \\
\text { Variation } \\
\text { Building) }\end{array}$ & & & & & \\
$\begin{array}{c}\text { SDN 8 } \\
\text { (Existing }\end{array}$ & 2 & 0,0542 & 0,0144 & 0,035 & $\checkmark$ \\
\cline { 2 - 6 } Building) & 1 & 0,0399 & 0,0399 & 0,035 & $\times$ \\
\hline $\begin{array}{c}\text { SDN 8 } \\
\text { Column }\end{array}$ & 2 & 0,0349 & 0,0137 & 0,035 & $\checkmark$ \\
\hline $\begin{array}{c}\text { Variation } \\
\text { Building) }\end{array}$ & 1 & 0,0211 & 0,0211 & 0,035 & $\checkmark$ \\
\end{tabular}

Based on Table 17, the variation of the column buildings in the two schools, the result of the inter-story drift in the y direction is smaller than the inter-story drift permit, so that it meets the provisions of SNI 1726-2019. While the results for the existing 1st floor buildings of SDN 48 and SDN 8 are greater than the inter-story drift permit. This is because the tsunami inundation reached 7 meters on the 2nd floor.

\subsection{Comparison of inter-story drift between earthquake and tsunami load}

Based on the results of the inter-story drift in Sections 4.6 and 4.10, a graph of the ratio of the inter-story drift to earthquake and tsunami loads can be seen in Fig. 15 and Fig. 16.

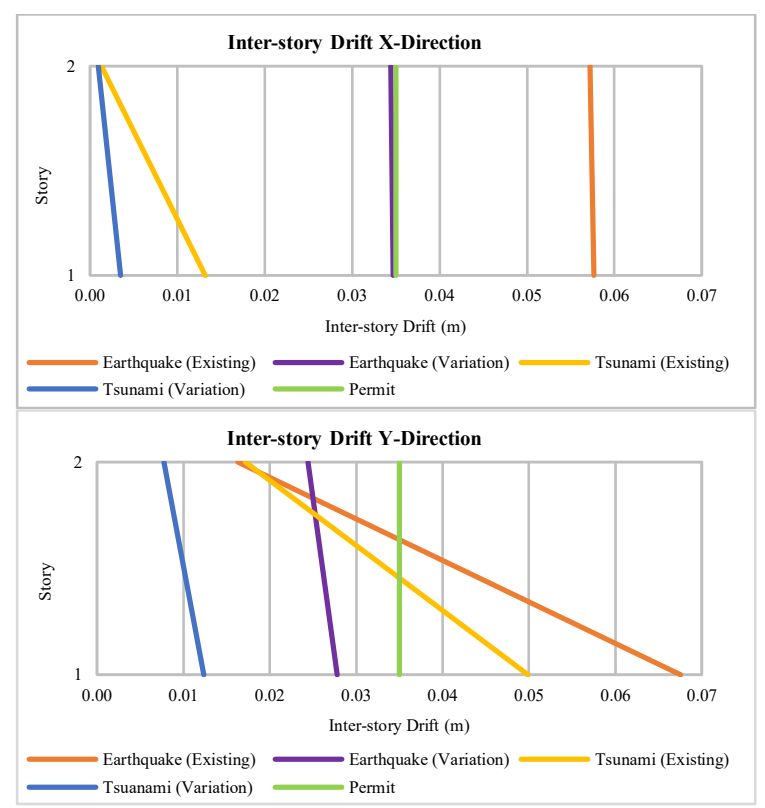

Fig. 15. The inter-story drift in the $x-y$ directions of SDN 48

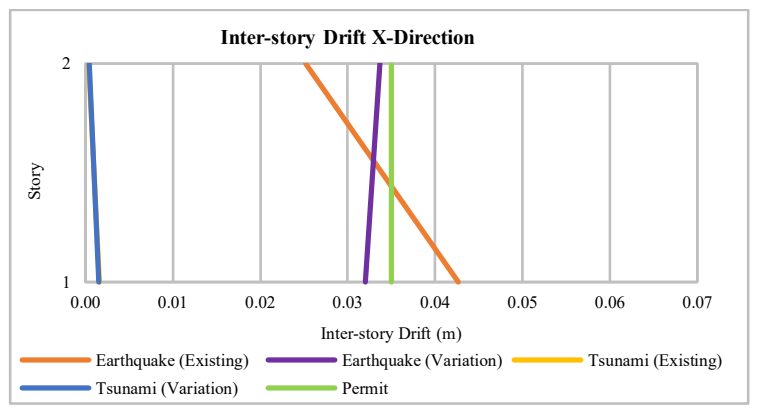

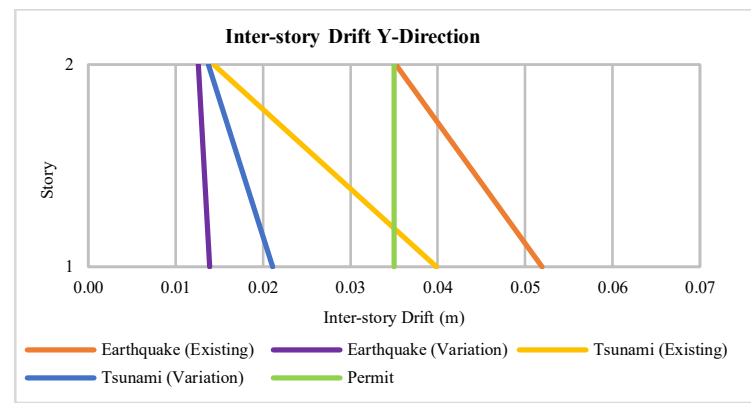

Fig. 16. The inter-story drift in the $x-y$ directions of SDN 8

The results of the inter-story drift due to earthquake and tsunami loads in the column variations of SDN 48 and SDN 8 have met the provisions of SNI 1726-2019 because the inter-story drift is not greater than the interstory drift permit. This shows that the addition of column dimensions affects the stiffness and behavior of the building structure, so that the building can withstand earthquake and tsunami loads.

\subsection{Evaluation results of the developed tsunami fragility curve}

The tsunami fragility curve used for this evaluation is the curve in the study of Syamsidik, et al (2020). The data required is the height of the tsunami inundation, which is $7 \mathrm{~m}$ for the buildings of SDN 48 and SDN 8 . The height data is inputted into the online graph-reader application and produces a probability value as shown in Fig. 17.

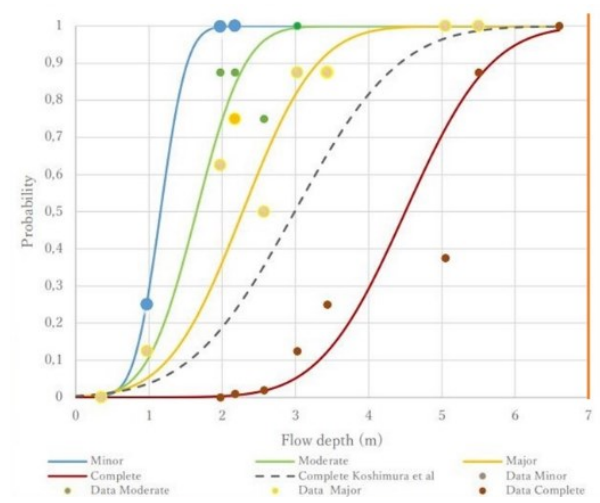

Fig. 17. Identify the probability of the developed tsunami fragility curve

The Fig.17 explains the relationship between tsunami inundation height and the probability value of the damage level to buildings. The inputted tsunami inundation height modeling that it was identified that there was no intersection between the inundation height line and the damage level. These results indicate that the probability value of the complete damage building that occurs for the SDN 48 and SDN 8 buildings is $100 \%$. However, if viewed from the structural behavior, namely the inter-story drift of the tsunami load, the column variation buildings for the two schools were able to withstand the tsunami load. Therefore, for tsunami loading, it is necessary to re-analyze the fragility curve that adjusts to the building structure. 


\section{Conclusions and suggestions}

\subsection{Conclusions}

1. Based on the earthquake and tsunami scenario in 2004, the existing buildings of SDN 48 and SDN 8 do not meet the structural boundary criteria of SNI 1726-2019. After being simulated with the addition of column dimensions, the results obtained for both buildings have met these criteria. This shows that the addition of column dimensions affects the behavior of the building structure.

2. The shear force value for the existing SDN 48 building do not meet the basic shear force requirements in SNI 1726-2019. The value obtained is very small compared to the shear force acting due to the earthquake. This is due to the small crosssectional area of the column.

3. The inter-story drift value due to earthquake loads for the existing buildings of SDN 48 and SDN 8 have not met the provisions of SNI 1726:2019. So that the two existing buildings are recommended for structural strengthening efforts.

4. The inter-story drift value due to the tsunami load for the existing buildings of SDN 48 and SDN 8 have not met the provisions of SNI 1726:2019. This is because the tsunami inundation reached 7 meters on the 2nd floor.

5. Based on the displacement value, after the addition of the column dimensions by $15 \%$, for the SDN 48 building, the displacement that occurs is reduced by $29 \%$ for the $\mathrm{x}$ direction and reduced by $26 \%$ for the $\mathrm{y}$ direction. While the SDN 8 building, the displacement that occurs after adding the column dimensions is reduced by $10 \%$ for the $\mathrm{x}$ direction and $28 \%$ for the y direction.

\subsection{Suggestions}

1. Using different structural modeling with different types of school buildings, such as the building shape, the height and width of the building, the number of story, or building materials.

2. Perform earthquake modeling with variations of other earthquake sources for earthquake load calculations in order to obtain different spectral response values.

3. Evaluating seismic performance by using a variety of structural reinforcement methods by reviewing other structural parts.

4. Analyze and evaluation of seismic and tsunami fragility curves according to data on school building structures.

\section{Reference}

1. BSN (Badan Standarisasi Nasional): SNI 1726:2019, Tata Cara Perencanaan Ketahanan Gempa untuk Struktur Bangunan Gedung dan non Gedung. Badan Standarisasi Nasional: Jakarta. Indonesia (2019)
2. BAPPENAS (Ministry of National Development Planning), Preliminary Damage and Loss Assesment; The December 26, 2004 Natural Disaster, Indonesia (2006).

3. X. Duan, J.W. Pappin, A Procedure for Establishing Fragility Functions for Seismic Loss Estimate of Existing Buildings Based on Nonlinear Pushover Analysis, presented on pada The $14^{\text {th }}$ World Conference on Earthquake Engineering, 12-17 October 2008, Beijing (2008)

4. FEMA (Federal Emergency Management Agency), Guidelines for Design of Structures for Vertical Evacuation from Tsunami Third Edition. Department of Homeland Security FEMA Mitigation Division: Washington D.C. (2019)

5. R. Gentile, C. Galasso, Y. Idris, I. Rusydy, E. Meilianda, From Rapid Visual Survey to MultiHazard Risk Prioritisation and Numerical Fragility of School Buildings, Nat. Hazards Earth Syst. Sci., 19, 1365-1386 (2019)

6. H. Iemura, M. H. Pradono, M. Sugimoto, Y. Takahashi, A. Husen, Tsunami Height Memorial Poles in Banda Aceh and Recommendations for Disaster Prevention, Proceedings of the International Symposium on Engineering Lessons Learned from the 2011 Great East Japan Earthquake, March 1-4, Tokyo, Japan (2012).

7. S. Koshimura, Y. Namegaya, H. Yanagisawa, Tsunami Fragility: A New Measure to Identify Tsunami Damage. Journal of Disaster Research. Vol. 4, No. 6, 479-488 (2009)

8. National Institute of Building Science (NIBS). HAZUS (Hazard US), (1999): Earthquake Loss Estimation, National Institute of Building Sciences. NIBS:Washington D.C (2002)

9. Y. A. Pranata, Evaluasi Kinerja Gedung Beton Bertulang Tahan Gempa dengan Pushover Analysis. Jurnal. Universitas Kristen Maranatha, Bandung. (2006)

10. N. T. Sugito, Tsunami, Universitas Pendidikan Indonesia, Bandung (2008)

11. Suharjanto. Rekayasa Gempa. Kepel Press: Yogyakarta (2013)

12. I. K. Sulendra, Evaluasi Dan Tindakan Pengurangan Kerusakan Bangunan. Jurnal. Universitas Tadulako, Palu (2011)

13. Syamsidik, Benazir, M. Lutfi, A. Suppasri, dan L. K. Comfort, The 22 December 2018 Mount Anak Krakatau volcanogenic tsunami on Sunda Strait coasts, Indonesia: tsunami and damage characteristics, NHESS, 20(2), 549-565 (2020).

14. Tursina, Syamsidik, Reconstruction of the 2004 Tsunami Inundation Map in Banda Aceh Through Numerical Model and Its Validation with PostTsunami Survey Data, IOP Conf. Series: Earth and Environmental Science 273 (2019)

15. N. A. Wibowo, Pengembangan Kurva Kerapuhan Berbasis Incremental Dynamic Analysis Untuk Evaluasi Kinerja Seismik Jembatan Beton. Jurusan Teknik Sipil Fakultas Teknik Universitas Sebelas Maret : Surakarta (2016) 